\begin{tabular}{cc|c}
\hline Tar. Bil. Der. & Tarm Bilimleri Dergisi & Journal of Agricultural Sciences \\
& $\begin{array}{c}\text { Dergi web sayfası: } \\
\text { www.agri.ankara.edu.tr/dergi }\end{array}$ & Journal homepage: \\
& www.agri.ankara.edu.tr/journal
\end{tabular}

\title{
Crown Gall Disease Susceptibility of Some Stone Fruit Rootstocks in Turkey
}

\author{
Sümer HORUZ ${ }^{\mathrm{a}}$, Behçet Kemal CAGLAR ${ }^{\mathrm{b}}$, Mustafa KUSEK ${ }^{\mathrm{c}}$, Yeşim AYSAN ${ }^{\mathrm{b}}$ \\ ${ }^{a}$ Erciyes University, Faculty of Agriculture, Department of Plant Protection, 38039, Kayseri, TURKEY \\ ${ }^{\boldsymbol{b}}$ Cukurova University, Faculty of Agriculture, Department of Plant Protection, 01330, Adana, TURKEY \\ ${ }^{c}$ Kahramanmaras Sütcu Imam University, Faculty of Agriculture, Department of Plant Protection, Kahramanmaras, TURKEY
}

\section{ARTICLE INFO}

Research Article DOI: 10.15832/ankutbd.490932

Corresponding Author: Sümer HORUZ, E-mail: sumer_536@yahoo.com, Tel: +90 (530) 3264129

Received: 13 June 2017, Received in Revised Form: 28 November 2017, Accepted: 30 November 2017

\begin{abstract}
Rhizobium radiobacter formerly known as Agrobacterium tumefaciens, is the most important bacterial pathogen causing crown gall disease on over 750 different plant species including ornamentals, vegetables and fruit trees. This pathogen causes crown galls on root and stems of plants and rarely on, above-soil parts of plants. Biological control is successfully used in disease management; however, such strategies are quite ineffective in disease contaminated soils or seedlings. Thus, growers and scientists are mostly focused on disease resistant cultivars or rootstocks.

In this study, crown gall disease reactions of three widely used rootstocks Garnem, Myrobolan and GF-677 for stone fruit trees were evaluated. A drop of bacterial suspension of $10^{9} \mathrm{cfu} \mathrm{mL}^{-1}$ were inoculated onto three individual wounds over 90 shoots per rootstock. The weights and sizes of the tumor formed were measured five months after rootstock inoculations. The size of produced galls on rootstocks Garnem, Myrobolan and GF-677 were 0.16-5.28 mm, 0.09-4.42 $\mathrm{mm}$ and $0.09-0.36 \mathrm{~mm}$, respectively. However, the weights of the galls varied between $0.02-2.85 \mathrm{~g}$ in Garnem, 0.01-1.58 $\mathrm{g}$ in Myrobolan and $0.02-0.11 \mathrm{~g}$ in GF-677 rootstocks. According to statistical analyses of gall formations, rootstocks were placed in different groups, additionally, none of them were found resistant to crown gall disease. Among the three rootstock tested, the study revealed that Garnem was highly susceptible, Myrobolan was moderately susceptible and GF-677 rootstock was less susceptible to crown gall disease. When an orchard will be intended to be newly planted with stone fruit trees, hence, GF-677 type rootstock would be a good choice to be preferred for planting in new orchards.

Keywords: Rhizobium radiobacter; Rootstock; Gall; Reaction
\end{abstract}

(C) Ankara Üniversitesi Ziraat Fakültesi

\section{Introduction}

Crown gall disease agent, Rhizobium radiobacter (synonym Agrobacterium tumefaciens) causes economically deleterious damages in over 750 plant species including woody plants like pome and stone fruit and nuts and ornamental woody crops like roses, as well as on grapevines and raspberries
(Kado 2002). This disease is of great significance for nurseries and results in scrapping of diseased trees reaching $80 \%$ or more (Moore 1990). Galls are formed on woody roots and at the base or crown of the infected plants. Gram-negative bacterium Rhizobium radiobacter is a rhizoplane pathogen, strictly aerobic and non-fastidious. Fresh crown 
galls are spheroidal, white to cream and smooth. As these galls age in years, the enlarged galls are crumbled and become brown and black. Aged galls are easily detached and diseased plant tissues are dead. Best sources of this pathogen are fresh galls, when there aren't any alive bacterium in plant tissues (Gelvin 2000). Crown gall disease has threatened the nurseries of stone (Aysan et al 2003), pome (Soylu et al 2011) fruits and rose (Aysan et al 2003) growers in Turkey since plants with tumors are unsalable and have to be discarded. Soil fumigation is a way to control, but it does not prevent entirely and use of chemicals is limited with new regulations, (Bliss et al 1999; Moriya et al 2008). Biological control using Agrobacterium radiobacter strain K84 or K1026 can provide a potential protection from the disease (Cooksey \& Moore 1982; Farrand 1990; Rhouma et al 2004). Recently, plantations of stone fruit trees that are fruiting early in the season increased in Turkey. Since the growers prefer seedlings in polythene bags or pots for plantations, it is impossible to use biological control agents for disease management. Use of resistant rootstocks in cultivation is the most effective strategy for disease control. In a field experiment, crown gall disease decreased with the usage of crown-gall resistant grapevine rootstocks (Sule \& Burr 1998). Many studies on crown gall disease resistance have been reported in woody plants, including fruit trees, grapevine and aspen (Szegedi et al 1984; Bliss et al 1999; Mahmoodzadeh et al 2004). A crown gall resistant wild apple was identified by Moriya et al (2008). This study suggested that a possible major gene could control the resistance in that wild apple, but probably, an additional minor genes were also responsible for the resistance. The knowledge about the crown gall resistance mechanisms is limited. A study reported that the crown gall reactions of aspen (Populus sp.) cultivars were related to differences in sensitivity to cytokinin (Beneddra et al 1996). The concentration of the Rhizobium radiobacter suspension can influence the gall occurrence in tested plant shoots. Moriya et al (2008) demonstrated that when the suspensions of strain CG8331 at a concentration of $10^{7} \mathrm{cfu} \mathrm{mL}^{-1}$ used in inoculation tests, the concentration was inadequate for gall occurrence in the tested genotypes. Thus, they have adapted to $10^{9} \mathrm{cfu} \mathrm{mL}^{-1}$ concentration of suspensions for evaluating crown gall disease resistance. Galls developed on genotypes with a frequency from 0.31 to 6.44 . Crown gall production often occurs on wounded plants. Wounds are the main openings for the pathogen to infect the plants. However, when the bacteria enter into the host plant, disease reaction may vary among several susceptible plants. Recently, stone fruit plantations including plum, apricot, nectarine and peaches have increased in the Eastern Mediterranean Region of Turkey. In these plantations, due to some advantages of rootstocks such as resistance to nematodes, calcareous soil and groundwater, growers mostly use hybrids of Prunus persica x Prunus amygdalus GF-677 and Prunus dulcis $x$ Prunus persica Garnem in nectarine and peach and Myrobolan for plum and apricot trees as rootstocks. In Turkey, the resistance of these rootstocks to Rhizobium radiobacter is unknown. The objective of this study was to screen three individual rootstocks used in stone fruit plantations for reaction to Rhizobium radiobacter. Evaluations were made according to emerged tumor weights and sizes at inoculated sections of 90 shoots.

\section{Material and Methods}

\subsection{Plant materials}

The peach rootstock of GF-677, almond x peach hybrid rootstock of Garnem and plum and apricot rootstock of Myrobolan were supplied from a commercial nursery (Vitroplant, 01120, Adana, Turkey) in December 2014 (Table 1). Since these three rootstocks were used for stone fruit trees of the region, they were tested for crown gall resistance. They were grown in pots containing sterilized soil. All seedlings were kept in a glasshouse at Plant Protection Department Research and Development Station of Cukurova University. The temperature of the glasshouse was $15-20{ }^{\circ} \mathrm{C}$. Other cultural practices such as irrigation, fertilization, pest management were routinely performed. 
Table 1- Geographic and genetic origin of rootstocks

\begin{tabular}{lll}
\hline Rootstock name & Originated from & Genetic origin \\
\hline GF 677 & France & Prunus persica $x$ Prunus amygdalus \\
Garnem & Spain & Prunus dulcis $x$ Prunus persica \\
Myrobolan & USA & Prunus cerasifera \\
\hline
\end{tabular}

\subsection{Preparation of bacterial inoculum}

Rhizobium radiobacter strain ECG-1 isolated from an infected apple tree was used in resistance studies (Soylu et al 2011). Bacterial pathogen was grown on King's Medium B (King B) $\left(10 \mathrm{~g} \mathrm{~L}^{-1}\right.$ proteose pepton, $10 \mathrm{~g} \mathrm{~L}^{-1}$ tryptone, $1.5 \mathrm{~g} \mathrm{~L}^{-1} \mathrm{MgSO}_{4} \cdot 7 \mathrm{H}_{2} \mathrm{O}$, $1.5 \mathrm{~g} \mathrm{~L}^{-1} \mathrm{~K}_{2} \mathrm{HPO}_{4}, 10 \mathrm{~mL} \mathrm{~L}^{-1}$ glycerol, $15 \mathrm{~g} \mathrm{~L}^{-1}$ agar, $\mathrm{pH} 7.2$ ) for $48 \mathrm{~h}$ at $25{ }^{\circ} \mathrm{C}$. The bacterium were transferred in a glass tube containing $12 \mathrm{~mL}$ of the growth medium and preserved at $+4{ }^{\circ} \mathrm{C}$ for short use. Additionally, the bacterial culture was stored at $-20{ }^{\circ} \mathrm{C}$ in $20 \%$ glycerol for longer storage. Before inoculation to shoots, the prepared bacterial suspension was measured using a spectrophotometer with dilution plate technique (Klement et al 1990) and adjusted to $10^{9}$ colony forming unit (cfu) $\mathrm{mL}^{-1}$ for inoculation.

\subsection{Pathogenicity of Rhizobium radiobacter strain ECG-1}

The pathogenicity of Rhizobium radiobacter strain ECG-1 was tested on kalanchoe (Kalanchoe daigramontiana) seedlings and fresh carrot (Daucus carota) slices. Kalanchoe plants were grown in pots in a chamber room under the following conditions: $16 \mathrm{~h}$ light $/ 8 \mathrm{~h}$ dark. The average height of plants used for inoculations was $10 \mathrm{~cm}$. Rhizobium radiobacter strain ECG-1 yielded onto $\mathrm{KB}$ at $25{ }^{\circ} \mathrm{C}$ for $48 \mathrm{~h}$. The bacterium was inoculated by wounding ten individual kalanchoe leaves and stems using sterilized toothpicks. Inoculated kalanchoe seedlings were kept at $25^{\circ} \mathrm{C}$ under $16 \mathrm{~h}$ light $/ 8 \mathrm{~h}$ dark photoperiod for 45 days to monitor gall formations. Carrot tubers about $20 \mathrm{~cm}$ height were disinfected with $70 \%$ ethanol for 5 minutes and right after rinsed in distilled water. Three carrot tubers were peeled with a sterile knife and $5.0 \mathrm{~mm}$ slices were placed onto sterilized blotters in $90 \mathrm{~mm}$ petri dishes. Bacterial culture was inoculated onto the slices by wounding. All petri dishes including carrot slices were moisturized with $1.5 \mathrm{~mL}$ sterile distilled water and kept in an incubator at $25{ }^{\circ} \mathrm{C}$ for 10-14 days. Sterile distilled water was inoculated to kalanchoe seedlings and carrot slices as control treatment.

\subsection{Rootstock inoculations}

The methods used by Bliss et al (1999), Moriya et al (2008) and Moriya et al (2010) were modified for rootstock inoculations. The inoculation was conducted in December, 2014 while all the new shoots were $25-30 \mathrm{~cm}$ long. The shoots were inoculated from three sites of each potted plant at the third and fourth internodes by wounding tissues $(0.5 \times 0.5 \times 0.5 \mathrm{~cm})$ with a scalpel. One drop of $6 \times 10^{9}$ cfu $\mathrm{mL}^{-1}\left(\mathrm{OD}_{600}=0.2\right)$ bacterial suspension $(20 \mu \mathrm{L})$ was injected into each wound. 30 potted plants of each rootstock were included in the study. Since three sites of each potted plant was used for inoculations, in total, 90 sites of each rootstock was inoculated. Each wound was covered with parafilm to avoid drying of the bacterial suspension. Distilled water was injected into control plant wounds. Inoculated plants were kept at $15-20{ }^{\circ} \mathrm{C}$ in a glasshouse of Cukurova University.

\subsection{Evaluation of crown gall resistance of rootstocks}

Five months after inoculation, each inoculated site was visually monitored and the diameter of formed galls were measured for each wound on plants and galls were picked to be weighed. Statistical analyses were conducted using analysis of variance (ANOVA) with CoStat Statistics Software (CoHort Software, Pacific Grove, CA, U.S.A. Version 6.4). Treatment means were compared with the Duncan's 
multiple range test $(\mathrm{P} \leq 0.05)$. Resistance levels of each rootstock were classified into three groups as described by Sule et al (1994) and Moriya et al (2008) according to statistical analyses of gall sizes and weights.

\section{Results and Discussion}

The Rhizobium radiobacter strain ECG-1 formed galls on wounded kalanchoe leaves and stems 45 days after inoculations. Gall formations were observed on carrot slices 10-14 days after inoculations. No gall formations were produced on control seedlings and carrot slices.

Five months after inoculations, Rhizobium radiobacter strain ECG-1 formed typical crown galls on wounded tissues of three individual rootstocks. Table 2 shows the results of mean gall sizes and weights after shoot inoculations with Rhizobium radiobacter isolated from apple. Crown gall disease resistance levels of three individual rootstocks was defined by statistical analysis and marked with different letters (Table 2). The mean gall sizes and weights ranged between $0.20-2.35 \mathrm{~mm}$ and between 0.05-1.04 g in all tested rootstocks. Rhizobium radiobacter strain ECG-1 induced large tumors as between $0.16-5.28 \mathrm{~mm}$ on Garnem rootstocks and the weights of tumors were between $0.02-2.85 \mathrm{~g}$. Gall formations on Garnem genotype were significantly different from the other rootstocks. Moderate tumors were induced by R.radiobacter on inoculated shoots of Myrobolan rootstock up to $4.42 \mathrm{~mm}$ in size and $1.58 \mathrm{~g}$ in weight. According to statistical evaluation, gall formations on Myrobolan were significantly different from the other rootstocks. GF-677 rootstocks had small galls with $0.09-0.36 \mathrm{~mm}$ in size and $0.02-0.11 \mathrm{~g}$ in weight. In statistical analysis on gall sizes and weights, GF-677 genotypes could be placed as a separate group different from Garnem and Myrobolan rootstocks. According to statistical analysis, the results demonstrated that Garnem rootstock was highly susceptible rootstock, however, Myrobolan was moderately susceptible and GF-677 was the least susceptible rootstocks to crown gall disease caused by Rhizobium radiobacter (Table 2). Pierronnet \& Salesses (1996) tested 87 Prunus genotypes and reported that Prunus cerasifera including Myrobolan rootstock were susceptible to crown gall. Zoina \& Raio (1999) tested six peach rootstocks (Barrier 1, GF677, Mariana GF8-1, Mr.S.2/5 and Peach seedling) for crown gall disease susceptibility levels by using several strains of Agrobacterium tumefaciens. Plants were wounded and inoculated in the roots and shoots, two inoculation methods were highly correlated. Except Mr.S.2/5, all the tested rootstocks showed high sensitivity to crown gall disease. Thomidis et al (2005) evaluated the susceptibility of five Prunus rootstocks (GF677, Antafuel, St. Julien 655/2, Peach seedling and Gisela 5) to Agrobacterium tumefaciens and the virulence of three individual Agrobacterium tumefaciens isolates from Prunus species. The researchers indicated that none of the tested rootstocks was resistant to crown gall disease and among all tested rootstocks, St. Julien 655/2 was the most resistant.

Among the different strains used, the level of susceptibility did not vary with the tested rootstocks. Rhouma et al (2005) also reported the same results indicating that almond and peach rootstocks were highly susceptible to A. tumefaciens. In the present study, according to produced mean gall sizes and weights, three tested rootstocks Garnem, Myrobolan

Table 2- Crown gall sizes and weights of Garnem, Myrobolan and GF-677 rootstocks after shoot inoculations with Rhizobium radiobacter strain ECG-1

\begin{tabular}{lcccc}
\hline Rootstocks & Range of gall size & $\begin{array}{c}\text { Mean gall size } \\
(\mathrm{mm})\end{array}$ & Range of gall weight & $\begin{array}{c}\text { Mean gall weight } \\
(\mathrm{g})\end{array}$ \\
\hline Garnem & $0.16-5.28$ & $2.35^{\mathrm{a}}$ & $0.02-2.85$ & $1.04^{\mathrm{a}}$ \\
Myrobolan & $0.09-4.42$ & $1.68^{\mathrm{b}}$ & $0.01-1.58$ & $0.59^{\mathrm{b}}$ \\
GF-677 & $0.09-0.36$ & $0.20^{\mathrm{c}}$ & $0.02-0.11$ & $0.05^{\mathrm{c}}$ \\
\hline
\end{tabular}


and GF677 were susceptible to Rhizobium radiobacter, like indicated in previous works. Various authors (Bush \& Pueppke 1991; Sule \& Burr 1998; Zoina \& Raio 1999) established that less susceptible plant genotypes permit the transfer of T-DNA, but these are failed in T-DNA integration. Integration of T-DNA is critical for tumor inducing. This limited tumor induction may be caused by a low rate of T-DNA integration in host plant.

The susceptibility level of crown gall disease can vary among different strains and concentration of the suspensions. Moriya et al (2008) indicated

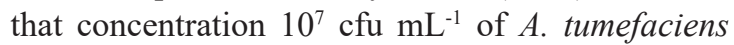
suspensions was inadequate for evaluating disease sensitivity of apple rootstocks. Researchers suggested $10^{9} \mathrm{cfu} \mathrm{mL}^{-1}$ suspension for the evaluation of crown gall resistance. This high concentration

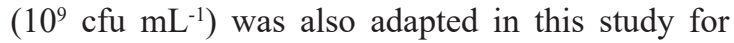
better results of an inoculation test to evaluate Rhizobium radiobacter sensitivity of rootstocks widely used in Turkey. Galls were produced at 90 individual inoculation sites of all tested rootstocks.

Garnem, Myrobolan and GF677 are widely used rootstocks in Turkey, however they are susceptible to crown gall like the other stone fruit rootstocks. Several authors were tested rootstocks of GF-677 and Myrobolan for crown gall disease (Pierronnet \& Salesses 1996; Bliss et al 1999; Zoina \& Raio 1999; Rhouma et al 2005; Thomidis et al 2005). None of studies tested both three rootstocks in the same work. In this study, susceptibility of rootstock Garnem to crown gall disease was also investigated. Current outcomes are probably the first report indicating that the rootstock Garnem was highly susceptible to crown gall infections.

\section{Conclusions}

Crown gall is one of the most destructive diseases of pome and stone fruits worldwide. Pathogenic bacterium, Rhizobium radiobacter, is soil-borne and can be encountered in most soils. Since the pathogen can infect the plants via wounds, use of disease resistant rootstocks enhance the disease control in newly planted orchards. Sources of disease resistance have been reported in some plant species, but the knowledge about the susceptibility level of pome and stone fruit rootstocks is very poor. In this study, crown gall disease reactions of most commonly used rootstocks Garnem, Myrobolan and GF677 in Turkey were tested. Statistically significant differences were observed among three rootstocks with regard to their resistance to the strain of Rhizobium radiobacter. None of tested rootstocks was resistant to the disease. Garnem was the most susceptible, Myrobolan was moderately susceptible and GF 677 was the least susceptible to crown gall disease infection.

The virulence of tested Rhizobium radiobacter strain suggests that the pathogen was a devastating threat to stone and pome fruit trees grafted onto GF677, Myrobolan and Garnem rootstocks. Although none of the tested rootstocks were resistant to Rhizobium radiobacter, the rootstock GF677 would be a good choice to be preferred for growing in Turkey.

\section{Acknowledgements}

The authors thank Assoc. Prof. Dr. Zeki GOKALP (an expert in Agriculture and certified English translator) for revision of the manuscript. This study was financially supported by Cukurova University, Scientific Research Project Unit by a Grant number ZF-2013-BAP15.

\section{References}

Aysan Y, Sahin F, Mirik M, Donmez M F \& Tekman H (2003). First report of crown gall of apricot (Prunus armeniaca) caused by Agrobacterium tumefaciens in Turkey. Plant Pathology 52: 793

Beneddra T, Picard C, Petit A \& Nesme X (1996). Correlation between susceptibility to crown gall and sensitivity to cytokinin in aspen cultivars. Phytopathology 81: 440-443

Bliss F A, Almedhi A A, Dandekar A M, Schuerman P L \& Bellaloui N I (1999). Crown gall resistance in accessions of Prunus species. Hortscience 34: 326330

Bush A L \& Pueppke S G (1991). Cultivar-strain specificity between Chrysanthemum morifolium 
and Agrobacterium tumefaciens. Physiological and Molecular Plant Pathology 39: 309-323

Cooksey D A \& Moore L W (1982). Biological control of crown gall with an agrocin mutant of Agrobacterium radiobacter. Phytopathology 72: 919-921

Farrand S K (1990). Agrobacterium radiobacter strain K84; a model control system. (Ed: R R Baker) New Directions in Biological Control: Alternatives for Suppressing Agricultural Pest and Diseases, CRC Press, Boca Raton, USA, pp. 137-191

Gelvin S B (2000). Agrobacterium and plant genes involved in TDNA transfer and integration. Annual Review of Plant Physiology and Plant Molecular Biology 51: 223-256

Kado C I (2002). Crown gall. http://www.apsnet.org/ edcenter/Pages/phi.aspx (Access date: 10.05.2017)

Klement Z, Mavridis A, Rudolph K, Vidaver A, Perombelon M C M \& Moore L W (1990). Inoculation of plant tissues. In: Z Klement, K Rudolph \& D C Sands (Eds), Methods in Phytobacteriology, Akademiai Kiado, Budapest, Hungary, pp. 99

Mahmoodzadeh H, Nazemieh A, Majidi I, Paygami I \& Khalighi A (2004). Evaluation of crown gall resistance in Vitis vinifera and hybrids of Vitis spp. Vitis 43: 75-79

Moore L W (1990). Crown gall. In: A L Jones \& H.S Aldwinckle (Eds), Compendium of apple and pear disease, APS Press, St Paul, USA, pp. 64-65

Moriya S, Iwanami H, Takahashi S, Kotoda N, Suzaki K \& Abe K (2008). Evaluation and inheritance of crown gall resistance in apple rootstocks. Journal of the Japanese Society for Horticultural Science 77(3): 236-241

Moriya S, Iwanami H, Takahashi S, Kotoda N, Suzaki K, Yamamoto T \& Abe K (2010). Genetic mapping of the crown gall resistance gene of the wild apple Malus sieboldii. Tree Genetics and Genomes 6: 195-203

Pierronnet A \& Salesses G (1996). Behaviour of Prunus cultivars and hybrids towards Agrobacterium tumefaciens estimated from hardwood cuttings. Agronomie 16: 247-256

Rhouma A, Ferchichi A, Hafsa M \& Boubaker A (2004). Efficacy of the non-pathogenic Agrobacterium strains K84 and K1026 against crown gall in Tunisia. Phytopathologia Mediterranea 42: 167-176

Rhouma A, Boubaker A, Nesme X \& Dessaux Y (2005). Susceptibility of some stone and pome fruit rootstocks to crown gall. Phytopathologia Mediterranea 44: 275-284

Soylu E M, Ayhan N, Cakırbey S \& Soylu S (2011). Hatay ili elma bahçelerinde Agrobacterium tumefaciens'in neden olduğu kök boğazı uru hastalığının belirlenmesi. IV. Bitki Koruma Kongresi. Bildiriler: 28-30 Haziran, Kahramanmaraş, s. 371

Sule S \& Burr T J (1998). The effect of resistance of rootstocks to crown gall (Agrobacterium spp.) on the susceptibility of scions in grape vine cultivars. Plant Pathology 47: 84-88

Sule S, Mozsar J \& Burr T J (1994). Crown gall resistance of Vitis spp. and grapevine rootstocks. Phytopathology 84: 607-611

Szegedi E, Korbuly J \& Koleda I (1984). Crown gall resistance in east-Asian Vitis species and in their $V$. vinifera hybrids. Vitis 23: 21-26

Thomidis T, Exadaktylou E \& Tsipouridis C (2005). Susceptibility of five Prunus rootstocks to Agrobacterium tumefaciens. New Zealand Journal of Crop and Horticultural Science 33: 343-345

Zoina A \& Raio A (1999). Susceptibility of some peach rootstocks to crown gall. Journal of Plant Pathology 81: $181-187$ 